\title{
PENGARUH LINGKUNGAN KERJA INTERNAL TERHADAP SEMANGAT KERJA PEGAWAI PADA DINAS PEMBERDAYAAN MASYARAKAT DAN PEKON KABUPATEN LAMPUNG BARAT
}

\author{
Noventi $^{(1)}$, Husna Purnama ${ }^{(2)}$, Khairul Saleh $^{(3)}$ \\ Fakultas Ekonomi Universitas Sang Bumi Ruwa Jurai \\ noventi29@gmail.com,husna.purnama@fe.saburai.ac.id,khairul.saleh@fe.saburai.ac.id
}

\begin{abstract}
Abstrak. Lingkungan internal dikenal sebagai iklim organisasi yang meliputi macam-macam atribut lingkungan yang mempunyai hubungan dengan segi-segi dan efektivitas, khususnya atribut yang diukur pada tingkat individual. : Semangat kerja adalah melakukan pekerjaan secara lebih giat, sehingga dengan demikian pekerjaan diharapkan akan lebih cepat dan lebih baik. Identifikasi maslah : Lingkungan Kerja yang masih kurang nyaman di rasakan oleh pegawai Dinas Pemberdayaan Dan Pekon Kabupaten Lampung Barat, Semangat kerja pegawai Dinas Pemberdayaan Dan Pekon Kabupaten Lampung Barat yang masih belum optimal. Tujuan penelitian ini untuk mengetahui pengaruh Lingkungan Kerja Internal Terhadap Semangat Kerja Pegawai pada Dinas Pemberdayaan Dan Pekon Kabupaten Lampung Barat. Hasil pengujian menunjukkan bahwa nilai $R$ square sebesar 0.378 . Nilai $R$ square ini menunjukkan bahwa besarnya kontribusi variabel independen terhadap variabel dependen adalah sebesar $37,8 \%$. Pengujian dilakukan dengan menggunakan uji t pada tingkat keyakinan signifikansi $\alpha$ 0.05. Dari hasil dapat diketahui bahwa tingkat signifikansi sebesar $0.00<0.05$ dengan nilai thitung $>t_{\text {tabel }}$ yaitu $4.410>2.034$, dengan demikian hipotesis diterima yang berarti lingkungan kerja internal terhadap semangat kerja pada Dinas Pemberdayaan Masyarakat Dan Pekon Kabupaten Lampung Barat.
\end{abstract}

Kata kunci: Internal, Kerja, Lingkungan, Semangat.

\section{PENDAHULUAN}

Pembangunan Daerah sebagai bagian integral dari pembangunan Nasional tidak lepas dari prinsip-prinsip ekonomi, yang diwujudkan dengan memberikan kewenangan yang luas, nyata dan bertanggung jawab secara proposional dengan lebih menekankan pada prinsip "Demokrasi" peran serta masyarakat dan keadilan serta dengan memperhatikan potensi dan keanekaragaman Daerah. Paradigma baru pemerintah yang tidak lagi dominan melaksnakan proses pembangunan namun hanya bersifat katalisator dan fasilisator dalam proses pembangunan.

Menurut Gibson dalam Hessel (2008) dalam kaitannya dengan tujuan organisasi bahwa kegiatannya itu adalah mengejar tujuan dan sasaran yang dapat dicapai secara lebih efisien dan lebih efektif dengan tindakan yang dilakukan secara bersamasama. Organisasi merupakan suatu alat dalam mencapai tujuan dan sangat diperlukan oleh masyarakat, baik dalam bidang profit maupun jasa (pelayanan). Tujuan organisasi akan tercapai apabila tiap-tiap individu yang ada dalam organisasi sadar akan tugas, wewenang dan tanggung jawabnya sehingga pada akhirnya tujuan organisasi akan tercapai.

Konsep tingkat efektivitas organisasi menunjuk pada tingkat sejauh mana organisasi melakukan kegiatan atau fungsifungsi sehingga tujuan yang telah ditetapkan dapat tercapai dengan menggunakan secara optimal alat-alat dan sumber-sumber yang ada. Ini berarti bahwa pembicaraan mengenai efektivitas organisasi menyangkut dua aspek yaitu tujuan organisasi dan pelaksanaan fungsi atau cara untuk mencapai tujuan tersebut. 
Demikian juga dengan Dinas Pemberdayaan Masyarakat Dan Pekon Kabupaten Lampung Barat mempunyai tugas membantu Bupati dalam melaksanakan Urusan Pemerintahan dibidang pemberdayaan masyarakat dan pekon yang menjadi kewenangan Daerah dan tugas pembantuan yang diberikan kepada kabupaten. Untuk melaksanakan tugas sebagaimana dimaksud Dinas menyelenggarakan fungsi; perumusan kebijakan di bidang pemberdayaan masyarakat dan pekon; pelaksanaan kebijakan di bidang pemberdayaan masyarakat dan pekon; pelaksanaan, evaluasi dan pelaporan di bidang pemberdayaan masyarakat dan pekon; pelaksanaan administrasi Dinas; dan pelaksaan fungsi lain yang diberikan oleh bupati sesuai dengan tugas dan fungsinya.

Selain itu faktor lingkungan kerja merupakan faktor yang penting dan harus diperhatikan. Lingkungan kerja adalah segala sesuatu yang ada disekitar yang dapat mempengaruhi dirinya dalam menjalankan tugasnya (Pramudyo, 2010). Hal pertama yang harus diusahakan untuk memperbaiki kinerja karyawan adalah menjamin agar pegawai dapat melaksanakan tugasnya dalam keadaan yang memenuhi syarat, sehingga mereka dapat melaksanakan tugasnya tanpa mengalami ketegangan-ketegangan, atau dengan kata lain organisasi harus menyediakan lingkungan kerja yang baik bagi pegawainya. Suatu kondisi lingkungan kerja dikatakan baik atau sesuai apabila manusia dapat melaksanakan kegiatannya secara optimal, sehat, aman dan nyaman.

Lingkungan kerja yang diharapkan adalah yang aman, tentram, bersih, tidak bising, terang dan bebas dari segala macam ancaman maupun gangguan yang menghambat kerja pegawai. Secara fisik lingkungan dapat berupa lokasi tempat kerja, kondisi bangunan dan fasilitas kerja, sedangkan lingkungan non-fisik/psikologis meliputi keberadaannya sangat ditentukan oleh tindakan organisasi melalui cara-cara pengoperasian, yaitu proses penghimpunan Sumber Daya Manusia, modal dan peralatan dengan cara yang paling efisien untuk mencapai tujuan.

Lingkungan internal dikenal sebagai iklim organisasi yang meliputi macammacam atribut lingkungan yang mempunyai hubungan dengan segi-segi dan efektivitas, khususnya atribut yang diukur pada tingkat individual. Lingkungan eksternal adalah kekuatan yang timbul dari luar batas organisasi seperti kondisi ekonomi, pasar, dan peraturan pemerintah.

Hal ini akan mempengaruhi derajat kestabilan yang relatif dari lingkungan, derajat kompleksitas lingkungan, dan derajat kestabilan lingkungan. Dalam hubungan dengan lingkungan terdapat suatu pola di mana tingkat keterdugaan dari keadaan lingkungan disaring oleh para pengambil keputusan dalam organisasi. Melalui ketetapan persepsi yang tepat tentang lingkungan tersebut dan pengambil keputusan yang sangat rasional akan dapat memberikan sumbangan terhadap efektivitas organisasi.

Semangat kerja/moral kerja berasal dari kata morale. Pada umumnya moral dipergunakan untuk menggambarkan suasana yang dirasakan samar-samar/kabur di antara anggota-anggota suatu kelompok, masyarakat, atau perkumpulan. Apabila mereka merasa baik, maka pada umumnya orang-orang tersebut mempunyai morale yang tingggi (Moekijat, 2008). Sedangkan pengertian semangat kerja yang lain adalah semangat dalam individu-individu dan golongan dalam menjalankan kegiatankegiatannya (Reksohadiprodjo, 2012). Selanjutnya Alex S. Nitisemito (2008) mengatakan : Semangat kerja adalah melakukan pekerjaan secara lebih giat, sehingga dengan demikian pekerjaan diharapkan akan lebih cepat dan lebih baik. 
Fenomena yang ada di Dinas Pemberdayaan Masyarakat Dan Pekon Kabupaten Lampung Barat berkaitan dengan lingkungan kerja internal masih banyak kekurangan seperti ruangan kerja yang belum seluruhnya terpasang $\mathrm{AC}$, kantin yang masih bergabung dengan dinas lain, kebersihan kantor yang belum terjaga dengan baik sehingga dalam memberikan pelayanan kepada masyarakat masih terasa belum optimal

Hasil pengamatan menunjukan bahwa pegawai di Dinas Pemberdayaan Masyarakat Dan Pekon Kabupaten Lampung Barat terindikasi ada pegawai yang datang dan pulang kerja tidak tepat waktu, tidak masuk kantor dikarenakan rumah tinggal tidak di Kabupaten Lampung Barat dan jangkauan wilayah yang terlalu jauh dan sulit dijangkau karena masuk dalam kategori daerah sulit serta kemampuan kerja aparatur yang belum maksimal didalam melaksanakan beban kerja, sehingga mmempengaruhi semangat kerja pegawai juga menjadi rendah.

Terkait dengan belum optimalnya pelayaanan pegawai Dinas Pemberdayaan Masyarakat Dan Pekon Kabupaten Lampung Barat memang tidak bisa hanya dilihat dari jumlah rasio pegawai dan pelayanan yang diberikan tetapi sejauh mana meningkatkan profesionalisme dalam melaksanakan tugas pelayanan kepada masyarakat

Berdasarkan uraian tersebut, peneliti tertarik untuk melakukan penelitian yang berjudul: "Pengaruh Lingkungan Kerja Internal Terhadap Semangat Kerja Pegawai Pada Dinas Pemberdayaan Dan Pekon Kabupaten Lampung Barat".

\section{KAJIAN TEORI}

\section{Definisi Lingkungan Kerja}

Pada saat ini, lingkungan kerja dapat didesain untuk menciptakan hubungan kerja yang mengikat pegawai dalam lingkungannya. Hakekatnya lingkungan kerja telah menjadi rumah tangga kedua bagi pegawai.

Lingkungan kerja adalah hal-hal yang berhubungan atau ada dalam lingkungan pekerjaannya dan dapat mempengaruhi dirinya dalam menjalankan tugas yang diberikan, baik itu yang berhubungan dengan kebendaan atau fisik maupun yang berhubungan dengan manusia. Lingkungan kerja yang diharapkan adalah yang aman, tentram, bersih, tidak bising, terang dan bebas dari segala macam ancaman maupun gangguan yang menghambat kerja pegawai.

Secara fisik lingkungan dapat berupa lokasi tempat kerja, kondisi bangunan dan fasilitas kerja, sedangkan lingkungan nonfisik/psikologis meliputi keberadaannya sangat ditentukan oleh tindakan organisasi melalui cara-cara pengoperasian, yaitu proses penghimpunan Sumber Daya Manusia, modal dan peralatan dengan cara yang paling efisien untuk mencapai tujuan.

Dalam pengoperasian diperlukan struktur tugas (Streest M. Richard, 2009), yaitu tingkat perincian metode yang dipakai untuk melaksanakan tugas oleh organisasi, dalam pengoperasian menyangkut pula adanya hubungan imbalan yaitu tingkat batas pemberian imbalan tambahan seperti promosi dan kenaikan gaji yang didasarkan pada prestasi dan jasa, bukan pada pertimbangan lain seperti senioritas, favoritisme dan sebagainya.

Sebagai makhluk sosial, pegawai mempunyai dua kebutuahan sosial yang pokok, yaitu rasa bersatu dan dukungan. Rasa bersatu akan didapat dengan mengadakan komunikasi tentang apapun yang berhubungan dengan pekerjaan dapat dikerjakan bersama-sama. Sedangkan dukungan dapat diperoleh dari rekan kerja, atasan atau bahkan bawahan, baik berupa penghargaan maupun berupa bantuan jika sedang dibutuhkan. Hal ini dapat menjadi 
suatu motivasi bagi pekerja dalam melaksanakan tugasnya.

Dari uraian diatas terlihat bahwa lingkungan kerja yang khususnya berupa hubungan kerja yang baik dapat menjadikan suatu cara pemenuhan kebutuhan pekerja untuk mencapai kinerja optimal. Menurut Agus Ahyari (2010) lingkungan kerja adalah suatu lingkungan dimana karyawan bekerja, sedangkan kondisi kerja merupakan kondisi dimana karyawan tersebut bekerja.

Dengan demikian sebenarnya kondisi kerja termasuk salah satu unsur lingkungan kerja, dengan kata lain lingkungan kerja didalam suatu lembaga bukan hanya terdiri dari kondisi kerja saja melainkan kondisi kerja ditambah dengan beberapa aspek lain yang membentuk lingkungan kerja.

\section{Definisi Semangat Kerja}

Semangat kerja/moral kerja berasal dari kata morale. Pada umumnya moral dipergunakan untuk menggambarkan suasana yang dirasakan samar-samar/kabur di antara anggota-anggota suatu kelompok, masyarakat, atau perkumpulan. Apabila mereka merasa baik, maka pada umumnya orang-orang tersebut mempunyai morale yang tingggi (Moekijat, 2008). sedangkan pengertian semangat kerja yang lain adalah semangat dalam individu-individu dan golongan dalam menjalankan kegiatankegiatannya (Sukanto Reksohadiprodjo, 2012).

Selanjutnya Nitisemito, Alex S (2008) mengatakan Semangat kerja adalah melakukan pekerjaan secara lebih giat, sehingga dengan demikian pekerjaan diharapkan akan lebih cepat dan lebih baik. Pendapat yang sama juga terdapat dalam Ensiklopedia Manajemen, yaitu : Morale biasanya diartikan sebagai sikap dalam bentuk kesediaan anggota suatu kelompok untuk bekerja sama dalam mencapai tujuan (Komaruddin, 2009).
Sedangkan menurut Alexander Leighton, semangat kerja didefinisikan sebagai kemampuan sekelompok orang untuk bekerja sama dengan giat dan konsekwen dalam mengejar tujuan bersama (Moekijat, 2008). Bekerjasama menitikberatkan pada hakekat saling hubungan suatu kelompok dengan suatu keinginan yang nyata untuk bekerja sama dengan giat dan konsekwen, menunjukkan caranya untuk sampai kepada tujuan melalui disiplin bersama. Perusahaan yang karyawan-karyawannya mempunyai semangat kerja yang tinggi biasanya mempunyai jumlah absensi yang minim, keluh kesah sedikit, rendahnya perputaran tenaga kerja (labour turnover) dan tidak adanya masalah pribadi yang lain (Reksohadiprodjo, 2012).

Dari uraian di atas dapat ditarik kesimpulan bahwa semangat kerja adalah merupakan suatu perilaku dari para karyawan terhadap pekerjaan mereka, pimpinan mereka, terhadap peraturan dan terhadap kondisi-kondisi dimana mereka bekerja, atau dengan kata lain dapat dilihat dari faktor psikologis, faktor sosial maupun faktor fisik pada karyawan dan perusahaan yang bersangkutan. Maka diharapkan dengan semangat yang ada akan dapat membantu kepada kemauan dan pelaksanaan tugas-tugas yang diperlukan untuk mencapai tujuan perusahaan.

\section{Faktor-Faktor yang Mempengaruhi Semangat Kerja}

Selanjutnya menurut Sukanto Reksohadiprodjo, ada beberapa faktor yang dapat mempengaruhi semangat kerja yang menjadikan pegawai mempunyai semangat kerja yang tinggi. Faktor-faktor tersebut secara umum, adalah :

1. Kepuasan dalam pekerjaan merupakan syarat untuk lebih maju.

2. Pimpinan langsung yang menghargai pegawai sebagai manusia dan 
menganggap bahwa pekerjaannya itu adalah penting.

3. Adanya jaminan dalam tugas untuk menjalankan tugas sebaik-baiknya.

4. Adanya hubungan baik dengan kolegakolega lain dan orang merasa berada dalam grup tertentu.

5. Upah dan lain-lain berbentuk kompensasi yang sama bagi setiap orang yang menjalankan tugas yang sama.

6. Perhatian organisasi untuk kemakmuran pegawai dan kemajuan-kemajuannya.

7. Kebanggaan dalam perusahaan (mengenai produksi dan statusnya dalam masyarakat) (Reksohadiprodjo (2012).

Berdasarkan pendapat diatas, maka selain pemberian perangsang yang berbentuk materi, maka semangat kerja juga dapat dipengaruhi oleh faktor-faktor yang bersifat non materi. Jadi dapat diambil kesimpulan, apabila pegawai tersebut dapat bekerja untuk memenuhi kebutuhannya dikarenakan adanya faktor perangsang yang berbentuk material maupun non material, maka semangat kerja pegawai akan meningkat.

\section{METODE PENELITIAN}

\section{Objek Penelitian}

Objek penelitian ini adalah pegawai di Dinas Pemberdayaan Masyarakat Dan Pekon Kabupaten Lampung Barat, yang beralamat Jln.Mawar No.3 Komplek Pemda Liwa Lampung Barat. Penelitian ini di laksanakan dari bulan April sampai dengan Juli 2018.

\section{Metode dan Teknik Pengumpulan Data}

Metode pengumpulan data merupakan cara atau teknik dalam proses pengumpulan data penelitian. Sehubungan dengan jenis penelitian desain kausal.
Untuk mendapatkan dan mengumpulkan data yang sesuai dengan kebutuhan dalam penelitian ini, maka metode pengumpulan data yang digunakan adalah sebagai berikut :

1. Data primer yaitu jenis data yang dikumpulkan dan diolah langsung dari objek penelitian yaitu dari Kantor Dinas Pemberdayaan Masyarakat Dan Pekon Kabupaten Lampung Barat seperti catatan, agenda, dokumen dan lain-lain.

2. Data Sekunder yaitu data yang bersumber dari luar objek penelitian seperti buku-buku, majalah, yang berkaitan dengan masalah penelitian ini.

Langkah-langkah pengumpulan data yang penulis lakukan dengan mengadakan penelitian lapangan yaitu penelitian yang dilakukan pada Kantor Dinas Pemberdayaan Masyarakat Dan Pekon Kabupaten Lampung Barat, adapun teknik yang digunakan dalam pengumpulan data adalah dengan :

1. Observasi

Yaitu mengadakan survey atau pengamatan langsung ke lokasi penelitian.

2. Interview atau wawancara Yaitu mengadakan tanya jawab langsung dengan pegawai pada Kantor Dinas Pemberdayaan Masyarakat Dan Pekon Kabupaten Lampung Barat.

3. Dokumentasi

Yaitu mengumpulkan dan mencatat dokumentasi yang relevan.

4. Quisioner

Yaitu membuat pertanyaan yang berhubungan dengan varibael penelitian. 


\section{Sampel dan Populasi}

Sampel penelitian adaalah sebagian dari populasi yang mewakili sifat dan karakter yang sama. Dengan mengambil sampel dimaksudkan untuk menyederhanakan jumlah subjek yang harus diteliti, tetapi hasil penelitian terhadap sampel itu akan digeneralisasikan pada populasi yang ada. Untuk menentukan banyak sampel, peneliti menggunakan pedoman dari pendapat Suharsimi Arikunto (2007) maka apabila subyeknya kurang dari 100, lebih baik diambil semua sehingga penelitiannya merupakan penelitian populasi. Selanjutnya jika jumlah subyeknya besar, dapat diambil 10\%-15\% atau 20\% - 25\% atau lebih.

Dalam penelitian ini, penulis tidak menggunakan sampel penelitian dikarenakan jumlah pegawai yang ada di Dinas Pemberdayaan Masyarakat Dan Pekon Kabupaten Lampung Barat berjumlah kurang dari 100 orang maka dalam penelitian ini penulis menggunakan data populasi seluruh pegawai yang ada yaitu berjumlah 34 orang pegawai.

\section{Metode Analisis Data}

Analisis kualitatif merupakan analisis yang dinyatakan dalam bentuk uraian dan didasarkan pada data yang telah ada. Data kualitatif merupakan data berupa informasi yang kemudian dikaitkan dengan data lainnya sehingga memunculkan suatu kebenaran. Analisis ini berguna untuk menjelaskan tentang berbagai macam masalah atau hal-hal penting yang dinyatakan dalam bentuk kalimat.

Analisis kuantitatif adalah metode analisis dengan angka-angka yang dapat dihitung maupun diukur, dan dalam prosesnya menggunakan alat bantu statistik. Statistik sendiri merupakan cara-cara ilmiah yang digunakan untuk mengumpulkan, mengolah, menganalisis, dan menginterpretasikan data berupa angkaangka, kemudian menarik kesimpulan atas data tersebut, dimana data tersebut disajikan dalam bentuk tabel, grafik, atau gambar (Algifari, 2008).

Persamaan Regresi Linear Sederhana menentukan persamaan regresi linear sederhana untuk $\mathrm{X}$ :

$$
Y=a+b X+e
$$

Keterangan:

$$
\begin{aligned}
& \mathrm{Y}=\text { Semangat kerja } \\
& \mathrm{a}=\text { Konstanta } \\
& \mathrm{b}=\text { Koefisien regresi } \mathrm{X} \\
& \mathrm{X}=\text { Lingkungan kerja internal } \\
& \mathrm{e}=\text { Faktor kesalahan }
\end{aligned}
$$

Untuk mengetahui besarnya pengaruh, penghitungan koefisien korelasi tersebut kemudian dilanjutkan dengan Rumus Koefisien Determinasi atau Koefisien Penentu (KP):

$$
K P=(r)^{2} x 100 \%
$$

Untuk menguji secara hipotesis secara parsial digunakan Uji t dengan rumus :

$$
t_{\text {hitung }}=\frac{r \sqrt{N-2}}{\sqrt{1-r^{2}}}
$$

Keterangan:

$$
\begin{aligned}
& \mathrm{t}_{\text {hitung }} \quad=\text { Nilai } \mathrm{t} \\
& \mathrm{r}=\text { Koefisien Korelasi } \\
& \mathrm{N}=\text { Jumlah responden }
\end{aligned}
$$

Kriteria untuk Uji $\mathrm{t}$ adalah sebagai berikut :

a) Jika $t_{\text {hitung }}>t_{\text {tabel }}$ maka Ha diterima dan Ho ditolak.

b) Jika $t_{\text {hitung }} \leq t_{\text {tabel }}$ maka Ha ditolak dan Ho diterima. 


\section{HASIL DAN PEMBAHASAN}

\section{Uji Validitas}

Data penelitian yang telah dikumpulkan kemudian diolah untuk menguji kualitas data berupa uji validitas dan reliabilitas. Hasil uji validitas dapat dilihat pada Tabel 1.

Tabel 1. Hasil Uji Validitas Instrumen Variabel Lingkungan Kerja Internal

\begin{tabular}{lccc}
\hline Indikator & $\mathrm{r}$ hitung & $\mathrm{r}$ tabel & Keterangan \\
\hline $\mathrm{X} 11$ & 0.988 & 0.514 & Valid \\
$\mathrm{X} 12$ & 0.988 & 0.514 & Valid \\
$\mathrm{X} 13$ & 0.906 & 0.514 & Valid \\
$\mathrm{X} 14$ & 0.988 & 0.514 & Valid \\
\hline
\end{tabular}

Berdasarkan Tabel 1. nilai $\mathrm{r}$ hitung kompensasi lebih besar dari r tabel (0.514), sehingga seluruh indikator dinyatakan valid.

Tabel 2. Hasil Uji Validitas Instrumen Variabel Semangat Kerja

\begin{tabular}{lrrc}
\hline Indikator & $\mathrm{r}$ hitung & $\mathrm{r}$ tabel & Keterangan \\
\hline Y11 & 0.881 & 0.514 & Valid \\
Y12 & 0.881 & 0.514 & Valid \\
Y13 & 0.971 & 0.514 & Valid \\
Y14 & 0.881 & 0.514 & Valid \\
Y15 & 0.733 & 0.514 & Valid \\
\hline
\end{tabular}

Berdasarkan Tabel 2. hasil perhitungan menunjukkan bahwa seluruh indikator untuk variabel semangat kerja adalah lebih besar dari $\mathrm{r}$ tabel, sehingga seluruh indikator dinyatakan valid.

\section{Uji Reliabilitas Data}

Nilai reliabilitas konsistensi internal untuk koefisien Alpha Cronbach dinyatakan reliabel karena lebih besar dari 0,60. Dengan demikian item pengukuran pada masing-masing indikator dalam variabel-variabel penelitian dinyatakan reliabel dan selanjutnya dapat digunakan dalam penelitan.

\section{Analisis Kuantitatif}

Persamaan regresi linier sederhana adalah $\mathrm{Y}=13.385+0.466 \mathrm{X}$. Nilai konstanta yang diperoleh sebesar 13.385, hal ini berarti bahwa jika variabel independen (lingkungan kerja internal) adalah bernilai nol, maka besarnya semangat kerja yang terjadi adalah 13.385. Nilai koefisien regresi variabel lingkungan kerja internal (X) sebesar 0.466, hal ini menunjukkan bahwa setiap kenaikan satu satuan lingkungan kerja internal akan mengakibatkan kenaikan semangat kerja sebesar 0.466. Nilai $R$ square sebesar 0.378 , nilai $R$ square ini menunjukkan bahwa besarnya kontribusi variabel independen terhadap variabel dependen adalah sebesar $37,8 \%$, sedangkan sisanya sebesar 62,2\% ditentukan oleh variabel lain yang tidak teridentifikasi dalam penelitian ini.

Uji hipotesis yang menyatakan "lingkungan kerja internal terhadap semangat kerja." Pengujian dilakukan dengan menggunakan uji $t$ yang menunjukkan bahwa lingkungan kerja internal terhadap semangat kerja. Pengujian dilakukan dengan menggunakan uji t pada tingkat keyakinan signifikansi $\alpha 0.05$. Dari hasil tabel 4.7 dapat diketahui bahwa tingkat signifikansi sebesar $0.00<0.05$ dengan nilai $t_{\text {hitung }}>t_{\text {tabel }}$ yaitu $4.410>$ 2.034, dengan demikian hipotesis diterima yang berarti lingkungan kerja internal terhadap semangat kerja.

\section{KESIMPULAN DAN SARAN}

\section{Kesimpulan}

Berdasarkan hasil penelitian dan pembahasan dapat disimpulkan bahwa pengujian dapat menjawab hipotesis yang menyatakan "Lingkungan kerja internal terhadap semangat kerja pada Dinas Pemberdayaan Masyarakat Dan Pekon 
Kabupaten Lampung Barat." Pengujian dilakukan dengan menggunakan uji t yang menunjukkan bahwa lingkungan kerja internal terhadap semangat kerja. Pengujian dilakukan dengan menggunakan uji t pada tingkat keyakinan signifikansi $\alpha 0.05$, dapat diketahui bahwa tingkat signifikansi sebesar $0.00<0.05$ dengan nilai $t_{\text {hitung }}>$ $t_{\text {tabel }}$ yaitu $4.410>2.034$, dengan demikian hipotesis diterima yang berarti lingkungan kerja internal terhadap semangat kerja pada Dinas Pemberdayaan Masyarakat Dan Pekon Kabupaten Lampung Barat.

\section{Saran}

Adapun saran yang diajukan peneliti adalah sebagai berikut:

1. Kepala Dinas Pemberdayaan Masyarakat Dan Pekon Kabupaten Lampung Barat hendaknya membuat lingkungan kerja yang baik dan harmonis sehingga dapat memberikan semangat kerja kepada pegawai dalam hal peningkatan kinerja pegawai tersebut.

2. Dinas Pemberdayaan Masyarakat Dan Pekon Kabupaten Lampung Barat hendaknya memberikan tambahan fasilitas pendukung yang sesuai kepada sehingga dapat bekerja dengan baik sesuai dengan keinginan pegawai.

3. Kepala Dinas Pemberdayaan Masyarakat Dan Pekon Kabupaten Lampung Barat hendaknya memberikan rewand kepada pegawainya sesuai dengan kemampuan dan kualitas yang dimiliki sesuai dengan kinerjanya.

\section{DAFTAR PUSTAKA}

Arikunto, Suharsimi. 2010. Prosedur Penelitian. Edisi Kelima. Jakarta: Binneka Cipta.

Ahyari, Agus. 2010. Manajemen Personalia. Yogyakarta: Graha Ilmu.
Algifari. 2008. Metodologi Penelitian Bisnis. Jakarta: Rajawali Perdana.

As'ad, Moh. 2010. Pembinaan untuk Meningkatkan Kinerja Karyawan. Jakarta: PPM.

Flippo, Edwin B. 2009. Management Human Resources. Jakarta: Bineka Cipta.

Ghozali. 2011. Aplikasi Analisis Multivariate Dengan Program SPSS. Semarang: Badan Penerbit Undip.

Handoko, T. Hani. 2007. Manajemen Personalia dan Sumber Daya Manusia. Edisi 2. Yogyakarta: BPFE.

Komaruddin. 2009. Lingkungan Fisik Kerja. Jakarta: Rajawali Perdana.

Moekijat. 2008. Administrasi Kepegawaian suatu Pengembangan. Jakarta: Rajawali.

Pramudyo. 2010. Sumber Daya Manusia dan Produktivitas Kerja. Bandung: Alphabeta.

Reksohadiprodjo, Sukanto. 2012. Manajemen Sumber Daya Manusia. Jakarta: ANDI Offset.

Streest M. Richard, 2009, Develoving Human Resouces. Jilid 2. Salemba Empat. Jakarta: UI.

Sugiyono. 2010. Metode Penelitian Kuantitatif dan Kualitatif dan $R \& D$. Bandung: CV. Alphabeta.

Tiffin. 2008. Produktivitas dan Manusia Indonesia. Jakarta: Ghalia Indonesia. 